\title{
Regional engagement of locally anchored firms and its influence on socio-economic development in two peripheral regions over time
}

\author{
Sandra Bürcher \\ Institute of Geography \& Center for Regional Economic Development, University of Bern, \\ Bern, Switzerland
}

Hallerstrasse 12, 3012, Bern, Switzerland, sandra.buercher@giub.unibe.ch (+41 3163188 77)

\begin{abstract}
This article sets out to explore the ways locally anchored firms in peripheral regions influence regional social capital through regional engagement and how this contributes to socio-economic development. Through regional engagement firms shape regional contexts by generating concrete outcomes, such as setting up schools (structural aspect) and by possibly influencing regional bonding and bridging social capital (social aspect). To examine the effects of regional engagement and its possible influence on bonding and bridging social capital of regional firms, an analytical framework is developed distinguishing between inclusivelexclusive agency for inclusivelexclusive benefit. This article focuses on regional engagement in two Swiss peripheral regions, which have followed different development paths in spite of their common institutional framework and geographical proximity. This study aims to gain insight into the "how" of regional engagement and its influence on regional social capital and to examine the assumption of higher levels of regional social capital in a dynamic region from a long-term perspective (ca. 1850-2015). The findings of the qualitative research show that the dynamic Rhine Valley indeed disposes of higher levels of regional social capital than the less dynamic Toggenburg, which is related to the willingness offirms and other actors to collaborate for regional interests.
\end{abstract}

Keywords: peripheral regions; regional engagement; social capital; locally anchored firms; socio-economic development 


\section{Introduction}

This article sets out to explore the ways locally anchored firms in peripheral regions influence regional social capital through regional engagement and how this contributes to socio-economic development. Through regional engagement firms can shape "the contexts and networks a firm is involved in" (Lengauer \& Tödtling, 2010, p. 7), which makes it especially promising for firms in peripheral regions, where organizational and institutional thinness or a lack of adequate infrastructure are frequent (Trippl, Asheim, \& Miörner, 2016; Smallbone, 2009). Locally anchored firms can influence those unfavourable contexts by generating concrete outcomes, such as the establishment of schools or business associations contributing to structural regional development. At the same time, firms can contribute to socio-economic development by influencing regional social capital of firms in terms of collaboration among firms (bonding social capital) and between firms and other important actors (bridging social capital). High levels of regional social capital and favourable structural endowments seem to enhance regional competitiveness (Nussmüller, Lengauer, \& Tödtling, 2009).

There are only a few studies dealing with economic actors and their impact on socio-economic development in peripheral regions (Müller 2016). Recently, a growing strand of literature has examined the relationship between peripheral entrepreneurs and their socio-spatial contexts. Those studies found that entrepreneurs have developed a particular relationship to their place and their community which can lead to a social transformation of the region (McKeever, Jack, \& Anderson, 2015; Kibler, Fink, Lang, \& Muñoz, 2015; Korsgaard, Ferguson, \& Gaddefors, 2015; Vestrum, 2014).

However, this literature lacks a long-term perspective on regional engagement and its influence on socio-economic development. Yet, a historical perspective is of utmost importance to explain current structural and social contexts (Putnam, 1993). This article tries to fill this gap by investigating regional engagement of firms during a long period (1848 until 2015). Moreover, it takes into account possible negative outcomes of regional engagement by developing an analytical framework distinguishing between exclusive and inclusive benefits of regional engagement for regional firms and helps to examine its possible influence on regional social capital. The two case study regions Toggenburg and Rhine Valley are located in Switzerland. They are not peripheral in terms of long distances to the centre, but in terms of the experience of firms and regions to be away from economic (national) centres (Anderson, 2000). Although the case study regions are geographically close, they have followed different development paths. Qualitative methods are used to get in-depth insight into the "how" of 
regional engagement and its influence on socio-economic development and to examine if in the dynamic Rhine Valley the levels of regional social capital are higher than in the less dynamic Toggenburg.

This article responds to the claim to contextualize economic action (Welter, 2011; McKeever et al., 2015). It investigates the interplay of economic actors with socio-spatial contexts and their contribution to regional development that goes beyond firm growth and job creation from a long-term perspective. Its main contribution is to improve the understanding of the importance of locally anchored firms for socio-economic development in peripheral regions.

\section{Theoretical framework}

\subsection{Regional engagement of firms}

Corporate regional engagement means "the active involvement of companies in shaping and upgrading regional productive potentials" (Lengauer \& Tödtling, 2010, p. 2). It can be regarded as the instrument to "shape the contexts and networks a firm is involved in" (Lengauer \& Tödtling 2010, p. 7). The management literature employs similar approaches, such as corporate social responsibility (CSR) or corporate citizenship. Whilst corporate regional engagement concentrates on engagement with effects at the regional level, these approaches are not clear about the spatial scale (Lengauer \& Tödtling, 2010).

However, Johannisson underlines that "all human endeavour manifests itself locally" (1990, p. 61). Through regional engagement, firms can strengthen their socio-spatial embeddedness and finally become part of the local community. That means that places are more than areas of production and consumption. They have also a strong social component (Uzzi, 1997; McKeever et al., 2015). Interaction with community and place is important for regional firms as the local community has certain expectations towards them. Through donations and sponsoring, e.g., an enterprise reacts to those expectations, which increases the firm's acceptance in the local community. Nevertheless, this reactive engagement corresponds to a rather low degree of sociospatial embeddedness. When firms actively engage in regional development, they can increase their socio-spatial embeddedness (Heblich \& Gold, 2010). Reactive and active engagement go beyond operational functions of firms that contribute to regional development through the employment of regional work force or tax income, which is mandatory (Lengauer \& Tödtling, 2010). Instead, they are optional and outreach the core activities of a firm by still focusing on improving the conditions of doing business, often without immediate profitability, however (Uzzi, 1997). 
This article is interested in active engagement of firms and especially in the influence of regional engagement on regional social capital in terms of collaboration between firms (bonding social capital) and between firms and other important actors (bridging social capital) (Westlund $\&$ Gawell, 2012). The mobilisation of local actors seems to be an important factor to bring about change, especially in peripheral regions (Johannisson \& Nilsson, 1989).

This study analyses the effects of regional engagement of firms at the regional scale and takes into account personal engagement of decision-makers of firms that can be based on a feeling of responsibility vis-à-vis the region (Nussmüller et al., 2009). This perspective refreshes the conventional view of "corporate" regional engagement or "corporate" social responsibility that link regional engagement often to firm strategies (Lengauer \& Tödtling, 2010).

Previous literature has underlined the importance of contextualizing economic action (Welter, 2011; Anderson, 2000). This article responds to this claim by contributing to a better understanding of the socio-spatial embeddedness of firms and their influence on regional contexts through regional engagement.

\subsection{Regional engagement in the periphery}

Studies on the role of economic actors for socio-economic development in the periphery are sparse (Müller, 2016). Recently, a growing strand of literature has dealt with peripheral entrepreneurs and their relationship to and engagement for their community and place (McKeever et al., 2015; Jack \& Anderson, 2002; Vestrum, 2014). Baumgartner et al. found that "all kinds of entrepreneurship identified in European non-core regions aim to create added values locally" (2013, p. 18). For example, peripheral entrepreneurs run a business and at the same time, they engage in other activities, which are related to the community, such as health care or culture. Hence, they seem to have a particular attachment to the place where they are active and contribute to regional development in a more socio-economic sense (McKeever et al., 2015; Korsgaard \& Anderson, 2011; Kibler et al., 2015). This article aims to deepen the understanding of the importance of regional engagement of firms for socio-economic development in peripheral regions, where doing business is challenging.

Those challenges concern different regional contexts, such as labour, infrastructural, institutional or organizational contexts, which are strongly related to regional economic development (Trippl et al., 2016; Smallbone, 2009). When regional firms succeed in influencing those contexts through regional engagement, they can improve their structural business endowments (Nussmüller et al., 2009). For example, firms can influence the labour 
context by establishing an apprenticeship centre for regional work force, thereby contributing to structural development. At the same time, they possibly influence regional social capital contributing to socio-economic development. High levels of regional social capital seem to be especially important for firms in peripheral regions as by collaborating among themselves (bonding social capital) and with other important (supra-)regional actors (bridging social capital), such as municipalities or schools to improve their business environment, they can save costs and engender inclusive benefit (Callois \& Aubert, 2007).

This article aims at investigating regional engagement of firms, its concrete outcomes (structural transformation) and its influence on regional social capital (social transformation).

\subsection{The interplay between regional engagement and social capital}

Regional engagement can influence regional networks (Lengauer \& Tödtling, 2010) and therefore social capital, which can be defined as the "social networks [among individuals] and the norms of reciprocity and trustworthiness that arise from them" (Putnam 2000, p. 19). Hence, social capital has an objective, structural dimension consisting of "durable social networks of more or less institutionalized positive relationships" (van Oorschot 2006, p. 151) and a subjective, cultural dimension characterized by "a set of values and attitudes of individuals relating to trust, reciprocity and willingness to cooperate" (van Oorschot 2006, p. 151). Both dimensions of social capital combined "enable people to act collectively" (Woolcock \& Narayan 2002, p. 226), which leads to mutual benefit, increases the activities' effectiveness and reduces the risk of "opportunism and malfeasance" (Putnam 2000, p. 21).

Several authors have conceptualized social capital as the resources embedded in relations and concentrate on the individual level of social capital (Coleman, 1988; Kim \& Aldrich, 2005; Bourdieu, 1986). Other scholars employ the concept at a macro-level, by underlining that social capital can also be the property of a region or a country. They argue that high levels of aggregated social capital leads to improved political and economic performance of regions and countries (Fukuyama, 1995; Putnam, 2000). This corresponds to a comprehension of social capital as a public good, although Putnam (2000) underlines that social capital can have private and public aspects at the same time. However, social capital can also have negative consequences (Uzzi, 1997). Networks that are too exclusive can lead to an overall fragmentation at aggregated levels (Jack, 2005; Adler \& Kwon, 2002). This article concentrates on social capital in terms of the quality of collaboration of firms and other actors at the regional level. 
Social capital is a complex phenomenon that arises at multiple socio-spatial levels (Westlund $\&$ Bolton, 2003). It can be prerequisite, process and outcome at the same time (McKeever, Anderson, \& Jack, 2014). It interacts with regional engagement in terms of a prerequisite at the agency level. Agency of regional engagement can consist of one firm or more probably a group of firms that collaborate for common interests. That group can have exclusive characteristics and tend "to reinforce exclusive identities" (Putnam, 2000, p. 22). However, the group can also have inclusive characteristics and include "people across diverse social cleavages" (Putnam, 2000, p. 22). From a regional firms' point of view, a group is exclusive regarding its industrial composition, i.e. when only firms of one industry are represented and/or with regard to its spatial extent, i.e. when it only includes actors from a sub-regional level. Then, regional engagement engenders exclusive or inclusive benefits, by benefiting only one firm, one industry, a group of actors at a sub-regional level, or by benefiting large parts of regional firms (see table 1). In this case, social capital is process. Beyond benefiting the actors that engage, regional engagement can - deliberately or not - affect "bystanders" (Putnam, 2000). This article assumes that regional engagement can influence social capital of regional firms positively or negatively, depending on whether it generates inclusive or exclusive benefits (see table 1). In this case, social capital is outcome. When engagement influences regional social capital, the public aspect of social capital prevails, as large parts of regional firms and other actors are concerned (see Putnam, 2000). This article is interested in regional bonding social capital, defined as (the potential of) collaboration between regional firms and regional bridging social capital, defined as (the potential of) collaboration between regional firms and other important actors, such as municipalities (Westlund \& Gawell, 2012). Although regional engagement primarily influences the regional level, networks, collaboration and effects can concern the subregional, regional or supra-/extra-regional level.

Table 1. Agency of regional engagement, its effects and possible influence on regional social capital from a regional firms' point of view.

\begin{tabular}{|l|l|l|}
\hline \multicolumn{1}{|c|}{ Effects } & For exclusive benefit & For inclusive benefit \\
\hline $\begin{array}{l}\text { Egency } \\
\text { Onc firm or an exclusive } \\
\text { group (firms and possibly } \\
\text { other actors) }\end{array}$ & $\begin{array}{l}\text { Positive outcomes for an } \\
\text { individual or an exclusive } \\
\text { group -> Weakening social } \\
\text { capital of regional firms? }\end{array}$ & $\begin{array}{l}\text { Positive outcomes for an } \\
\text { inclusive group -> } \\
\text { Strengthening social capital } \\
\text { of regional firms? }\end{array}$ \\
\hline $\begin{array}{l}\text { Inclusive: An inclusive } \\
\text { group (firms and possibly } \\
\text { other actors) }\end{array}$ & $\begin{array}{l}\text { Positive outcomes for an } \\
\text { individual or an exclusive } \\
\text { group }->\text { Weakening social } \\
\text { capital of regional firms? }\end{array}$ & $\begin{array}{l}\text { Positive outcomes for an } \\
\text { inclusive group -> } \\
\text { Strengthening social capital } \\
\text { of regional firms? }\end{array}$ \\
\hline
\end{tabular}


Different forms of regional engagement with regard to agency and effects can lead to different patterns of social capital at the regional level by weakening or strengthening it. Weak regional social capital corresponds to a fragmented pattern consisting of different groups that lack collaboration. Strong regional social capital corresponds to a smoother pattern characterized by a higher degree of collaboration between different groups. This article assumes that levels of regional social capital are higher in dynamic than in less dynamic regions.

As "social capital in larger social aggregates [such as a region] has deep historical roots" (Adler $\&$ Kwon 2002, p. 21), it is crucial to employ a long-term perspective. Putnam (1993) underlines the importance of path-dependence to explain current characteristics of civic engagement by emphasizing that the successful north of Italy has a long tradition of collaboration contrary to the less developed south.

\section{Methodology}

Case studies are an appropriate choice for under-researched phenomena (Korsgaard \& Anderson, 2011), which is the case regarding the influence of regional engagement of firms on socio-economic development. The Swiss regions "Rhine Valley" and "Toggenburg" are especially suitable, as in both regions the textile industry prevailed in the 19th century. After its decrease (from the 1920s), they have followed different development paths. Their different development paths, in spite of their common institutional framework (they belong to the same canton) and their close geographical location, make them to particularly appropriate cases, as contrasting patterns can be observed more easily (Eisenhardt \& Graebner, 2007). Switzerland is an interesting case, as many successful firms or industries are located in the periphery (e.g. watchmaking in the Jura). Although distances are short, the development paths of peripheral regions are very heterogeneous.

As this research focuses on the "how" of regional engagement over time, rather than on the "how many", a qualitative approach is adequate (McKeever et al., 2014). Moreover, qualitative data offer "insight into complex social processes that quantitative data cannot easily reveal" (Eisenhardt \& Graebner, 2007, p. 26).

\subsection{Data collection}

I started data collection with a review of secondary literature (economic history of the regions, biographies, history of firms) and historical documents (annals of the regions, documents in archives) with a threefold aim. First, to get an overview of the industrial history of the two regions, which is important to understand regional engagement (Doloreux, Dionne, \& Jean, 
2007). Second, to identify key outcomes of regional engagement (structural aspect), its agency and possible influence on social capital (social aspect) of firms. The key outcomes are defined as results of regional engagement with the participation of one or several regional firms and concern the business environment. It was not the aim to have an exhaustive list of outcomes, but to reduce them to the most revealing ones. Through triangulation of data sources (Denzin, 1978) the validity of the selected key outcomes was checked by contacting regional historic experts, consulting different sources of secondary literature and asking interview partners.

For the most recent period, I consulted regional media and conducted 20 semi-structured interviews. To facilitate the access to regional firms, I was in contact with representatives of the regional development agencies. The main aim was to ask interviewees for key outcomes of regional engagement and their expert insights into regional engagement of firms. I applied the criterion sampling method (Patton, 2002) by choosing interviewees who have engaged for the region or have a vast knowledge of persons engaging for the region. Other criteria were different (i) ages of the firms, (ii) sizes, (iii) geographical locations within the regions, and (iv) industrial sectors (see table 2). The majority of the interviewees come from the corresponding region and are active in the manufacturing industry which is above Swiss average in both regions (Rhine Valley: $44.8 \%$, Toggenburg: $34.8 \%$, Switzerland: $22.4 \%$ of total employment in 2011 (Canton St. Gallen, specialist unit for statistics, 2013)). Four more interviews took place, namely with a person who could give historical information about an important firm, with the managers of the two regional development agencies and with the former head of the cantonal office for industry, commerce and employment and his collaborator. 
Table 2. Overview of the interviewed firms and persons.

\begin{tabular}{|c|c|c|c|c|c|}
\hline $\begin{array}{l}\text { Region } \\
\text { TB: } \\
\text { Toggen- } \\
\text { burg/RV } \\
\text { : Rhine } \\
\text { Valley }\end{array}$ & $\begin{array}{l}\text { Function of } \\
\text { interviewee }\end{array}$ & Industrial sector & $\begin{array}{l}\text { Creation of } \\
\text { the } \\
\text { firm/entry } \\
\text { into the } \\
\text { commercial } \\
\text { register* }\end{array}$ & Location & $\begin{array}{l}\text { Size (micro < } \\
9, \text { small } 10- \\
49, \text { medium } 50 \\
-249, \text { large }> \\
250 \text { employees) }\end{array}$ \\
\hline TB1 & $\begin{array}{l}\text { CEO (Chief } \\
\text { Executive Officer) }\end{array}$ & $\begin{array}{l}\text { Manufacture of other general- } \\
\text { purpose machinery n.e.c.** } \\
(\text { NOGA08***: 282900) }\end{array}$ & $1956 / 1956$ & Wattwil & Medium-sized \\
\hline TB2 & $\begin{array}{l}\text { CEO (from founder } \\
\text { family) }\end{array}$ & $\begin{array}{l}\text { Manufacture of other food products } \\
\text { n.e.c. (NOGA08: 108900) }\end{array}$ & $1930 / 1936$ & Ebnat-Kappel & Medium-sized \\
\hline TB3 & $\begin{array}{l}\text { Member of the } \\
\text { company } \\
\text { management (from } \\
\text { founder family) }\end{array}$ & $\begin{array}{l}\text { Forging, pressing, stamping and } \\
\text { roll-forming of metal; powder } \\
\text { metallurgy (NOGA08: 255000) }\end{array}$ & $1920 / 1993$ & Wattwil & Medium-sized \\
\hline TB4 & $\begin{array}{l}\text { Member of the } \\
\text { company } \\
\text { management (from } \\
\text { co-founder family) }\end{array}$ & $\begin{array}{l}\text { Manufacture of sports goods } \\
\text { (NOGA08: } 323000 \text { ) }\end{array}$ & $1891 / 1951$ & Ebnat-Kappel & Medium-sized \\
\hline TB5 & $\begin{array}{l}\text { CEO (from founder } \\
\text { family) }\end{array}$ & $\begin{array}{l}\text { Manufacture of household textiles } \\
\text { (NOGA08: 139201) }\end{array}$ & $1857 / 2013$ & Nesslau & Small-sized \\
\hline TB6 & CEO & $\begin{array}{l}\text { Manufacture of electronic } \\
\text { components (NOGA08: 261100) }\end{array}$ & 1991/1991 & Ebnat-Kappel & Medium-sized \\
\hline TB7 & CEO (founder) & $\begin{array}{l}\text { Manufacture of other parts and } \\
\text { accessories for motor vehicles } \\
\text { (NOGA08: 293200) }\end{array}$ & $1990 / 2013$ & $\begin{array}{l}\text { Bütschwil- } \\
\text { Ganterschwil }\end{array}$ & Micro-sized \\
\hline TB8 & $\begin{array}{l}\text { CEO (from founder } \\
\text { family) }\end{array}$ & $\begin{array}{l}\text { Manufacture of instruments and } \\
\text { appliances for measuring, testing } \\
\text { and navigation (NOGA08: 265100) }\end{array}$ & $1865 / 1903$ & $\begin{array}{l}\text { Bütschwil- } \\
\text { Ganterschwil }\end{array}$ & Medium-sized \\
\hline TB9 & CEO & $\begin{array}{l}\text { Manufacture of brooms and brushes } \\
\text { (NOGA08: } 329100 \text { ) }\end{array}$ & $1914 / 1923$ & Ebnat-Kappel & Medium-sized \\
\hline TB10 & $\begin{array}{l}\text { CEO (from founder } \\
\text { family) }\end{array}$ & $\begin{array}{l}\text { General building construction and } \\
\text { civil engineering works n.e.c. } \\
\text { (NOGA08: } 412003 \text { ) }\end{array}$ & $1938 / 1966$ & Wattwil & Medium-sized \\
\hline RV1 & $\begin{array}{l}\text { Member of the } \\
\text { company } \\
\text { management (from } \\
\text { founder family) }\end{array}$ & $\begin{array}{l}\text { Manufacture of tubes, pipes, hollow } \\
\text { profiles and related fittings, of steel } \\
\text { (NOGA08: 242000) }\end{array}$ & $1923 / 1923$ & Oberriet & Large-sized \\
\hline RV2 & CEO & $\begin{array}{l}\text { Manufacture of assembled parquet } \\
\text { floors (NOGA08: 162200) }\end{array}$ & $1936 / 1978$ & St.Margrethen & Large-sized \\
\hline RV3 & $\begin{array}{l}\text { CEO (President of } \\
\text { the employers' } \\
\text { association) }\end{array}$ & $\begin{array}{l}\text { Publishing of newspapers } \\
\text { (NOGA08: 581300) }\end{array}$ & $2011 / 2014$ & Berneck & Small-sized \\
\hline RV4 & $\begin{array}{l}\text { CEO (1999-2012), } \\
\text { from } 2013 \text { CEO } \\
\text { international group }\end{array}$ & $\begin{array}{l}\text { Manufacture of plastic packing } \\
\text { goods (NOGA08: 222200) }\end{array}$ & $1928 / 1928$ & Diepoldsau & Medium-sized \\
\hline RV5 & $\begin{array}{l}\text { Until } 2009 \text { CTO } \\
\text { (Chief Technology } \\
\text { Officer) }\end{array}$ & $\begin{array}{l}\text { Manufacture of optical instruments } \\
\text { and photographic equipment } \\
\text { (NOGA08: 267000) }\end{array}$ & $1921 / 1923$ & Balgach & Large-sized \\
\hline RV6 & $\begin{array}{l}\text { Head human } \\
\text { resources (from } \\
\text { founder family) }\end{array}$ & $\begin{array}{l}\text { Manufacture of fasteners and screw } \\
\text { machine products (NOGA08: } \\
259400 \text { ) }\end{array}$ & $1928 / 1960$ & $\mathrm{Au}$ & Large-sized \\
\hline RV7 & $\begin{array}{l}\text { Member of the } \\
\text { company } \\
\text { management } \\
\text { together with } \\
\text { husband (from } \\
\text { founder family) }\end{array}$ & $\begin{array}{l}\text { Manufacture of doors and windows } \\
\text { of metal (NOGA08: 251200) }\end{array}$ & $1966 / 2005$ & Oberriet & Small-sized \\
\hline RV8 & CEO & $\begin{array}{l}\text { Manufacture of other plastic } \\
\text { products (NOGA08: 222900) }\end{array}$ & $1956 / 1961$ & Widnau & Medium-sized \\
\hline RV9 & CEO & $\begin{array}{l}\text { Manufacture of plastic and rubber } \\
\text { machinery (NOGA08: 289600) }\end{array}$ & $1932 / 1944$ & Rüthi & Small-sized \\
\hline RV10 & CEO (founder) & $\begin{array}{l}\text { Mechanical workshops (NOGA08: } \\
\text { 256201) }\end{array}$ & 1998/1998 & Altstätten & Medium-sized \\
\hline
\end{tabular}

Sources: Interviews, Swiss Commercial Register, websites of the firms / * there are often deviations between the establishment of a firm as indicated on firm websites and its entry into the commercial register due to possible changes in legal status for example / **n.e.c.: not elsewhere classified / ***NOGA (Nomenclature Générale des Activités économiques): Swiss general classification of economic activities 2008. 


\subsection{Data analysis}

The data analysis is based on the three-step process suggested by Huberman and Miles (1994), which includes data reduction, data display, conclusion drawing and verification. For the reduction and display of the historical data, I employed the method of "temporal bracketing" (Langley, 1999), which helps to structure the rich data and to recognize patterns over time by regrouping outcomes of regional engagement within periods, which are demarcated by a change in the industrial structure of the region. I repeatedly reduced the collected outcomes until the key outcomes became obvious.

For the reduction of the interview data, I codified the transcribed interviews by combining deductive and inductive coding (Schreier, 2014) to identify relevant themes regarding the research question and the analytical framework introduced above and to distinguish insignificant information. For the display and comparison of the data, I created several thematic tables.

Finally, I drew conclusions based on the displayed data and checked them through data triangulation (Denzin, 1978), wherever possible. I alternated between theory and data to guarantee the coherence between findings and theory and my research question. The quotes below "are used to provide valuable supplements" and "to add voice to the text" (Jack \& Anderson, 2002, p. 473), in the form of power quotes (McKeever et al., 2015). I translated the quotes from German and labelled them with fictitious names to guarantee anonymity.

\section{Description of the case study regions}

Toggenburg (today's district Toggenburg) and the Rhine Valley (today's district Rhine Valley) are located in eastern Switzerland in the canton of St. Gallen outside the Swiss metropolitan regions Geneva-Lausanne, Bern, Basel, Zurich, and southern Ticino (Schuler, Dessemontet, \& Joye, 2005), which characterizes them as peripheral (Lagendijk \& Lorentzen, 2007) (see figure 4). 
Figure 1. The case study regions in eastern Switzerland: Toggenburg and Rhine Valley.

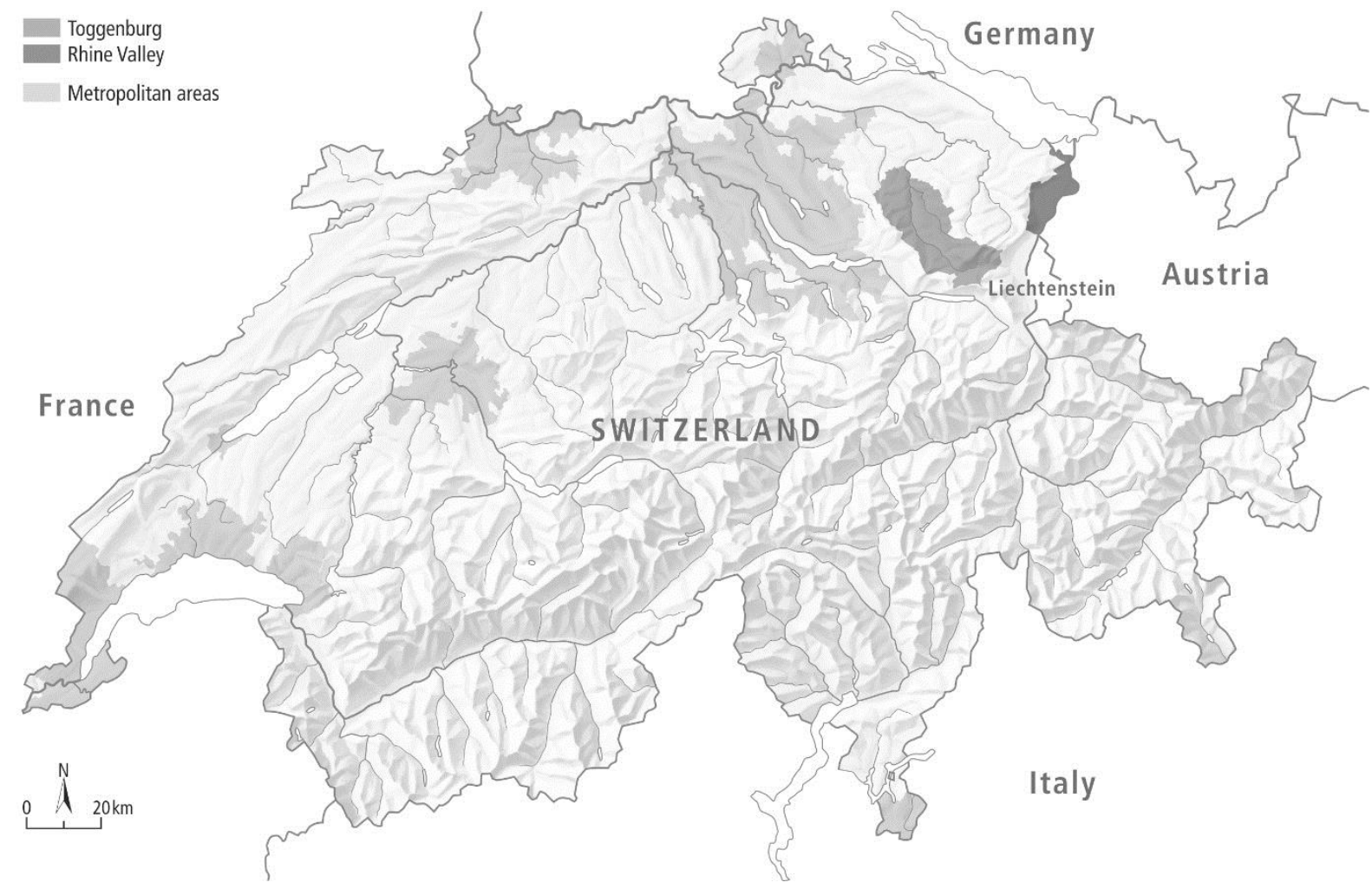

Source: Map base layer by the Swiss Federal Office of Topography, www.geo.admin.ch. Cartography by Alexander Hermann, Institute of Geography, University of Bern.

The total permanent resident population was 69,612 in the Rhine Valley and 45,261 in Toggenburg in 2013. The two regions are characterized by small towns: the two biggest municipalities in Toggenburg are Kirchberg and Wattwil with 8,522 and 8,425 inhabitants, respectively. The biggest municipality in the Rhine Valley is Altstätten with 11,168 inhabitants (Canton St. Gallen, specialist unit for statistics, 2013). The Rhine Valley shares a border with Austria and Liechtenstein.

Toggenburg is characterized by a decreasing number of inhabitants and employees and a low share of typical growing branches, such as high tech or electrical engineering (Anderegg, 2011). The number of employees in Toggenburg decreased slightly between 1990 and 2000, strongly however between 1990 and 2011/2013 (a total of -6\%). It was the only region in the canton of St. Gallen that lost employees in this period, which is related to the closing of the important Heberlein textile enterprise. The Rhine Valley that has developed into an important high-tech industry location over time, belongs to the regions with the largest growth in the number of employees (27\%) in the same period (Gröble, Benson, \& Flockerzi, 2015). 


\section{Findings}

The aim of this section is to analyse the different outcomes of regional engagement of firms over time by focusing on inclusive and exclusive benefit form a regional firms' point of view and its potential influence on regional bonding and bridging social capital based on the analytical framework introduced in the theory part.

\subsection{Exclusive agency for exclusive benefit}

\subsubsection{The long dominance of the Heberlein enterprise in Toggenburg}

Regional engagement in the form of exclusive agency creating exclusive benefit often negatively influences regional social capital (RSC).

This type of engagement was predominant in Toggenburg for a long period, as the Heberlein textile enterprise engaged out of firm interests with the main aim of binding the work force to the firm (Fischer \& Oswald, 1997) (see table 3, outcomes 7, 8 and 10).

Table 3. Outcomes of regional engagement of firms and impact on regional social capital in Toggenburg (exclusive agency for exclusive benefit).

\begin{tabular}{|c|c|}
\hline \multicolumn{2}{|c|}{ Phase 1: Beginning of the $19^{\text {th }}$ century to 1880 s "Boom of the colour-weaving industry" } \\
\hline Outcome 1 & 1848: Creation of an employers' association (textile industry) \\
\hline Impact on RSC* & Rather weakening RSC \\
\hline \multicolumn{2}{|c|}{ Phase 3: 1920s to 1980s "Growth and boom of the Heberlein enterprise" } \\
\hline Outcome 7 & 1924: Inauguration of the "Volkshaus" (public house) \\
\hline Impact on RSC & Rather weakening RSC \\
\hline Outcome 8 & 1939: Establishment of a residential complex for working-class families \\
\hline Impact on RSC & Rather weakening RSC \\
\hline Outcome 9 & 1943: Creation of the employers' association Ebnat-Kappel \\
\hline Impact on RSC & Rather weakening RSC \\
\hline Outcome 10 & $\begin{array}{l}\text { 1969: Construction of three multi-storey buildings for the members of the } \\
\text { management }\end{array}$ \\
\hline Impact on RSC & Rather weakening RSC \\
\hline
\end{tabular}

*RSC: Regional social capital.

The Heberlein enterprise (created in 1835 and led by several family generations) succeeded in adapting to the changing environment after the crisis of the textile industry in the 1920s. The enterprise experienced a boom, especially after World War II when they introduced Helanca, a polyamide filament yarn (Holenstein, 2015). While in 1895 only 45 employees worked at the Heberlein enterprise, in 1940 they were about 1,000 (Fischer \& Oberli, 1993), at the end of 1971 their number peaked with 2,434 employees (Wickli, 2015). The Heberlein family engaged 
for their employees by establishing a public house to promote cultural life and by building residences (Anderegg, 2015), which benefited the enterprise, its employees and the central municipality of Wattwil. Hence, benefit was exclusive regarding other regional firms and the geographical level. Peter, who knows the history of the Heberlein enterprise well, underlines:

The whole region understood that they were like a family, "the Heberlianer" [the members of the Heberlein enterprise], which was partially a problem, as there were certain aspects, only the employees of the Heberlein enterprise and their families benefited from, not the others (Peter TB, 2015).

This was a reason for collaboration among regional firms being largely absent. As a response, the heads of the firms of the adjacent municipality Ebnat-Kappel created their own employers' association (see table 3, outcome 9) to build a counterweight to the all-dominating Heberlein enterprise, as Emil confirms: "The struggle was for resources, that means who gets the employees? [...] This was the reason for the enterprises to engage in social projects, Heberlein was a pioneer with regard to social housing for the employees" (Emil TB, 2014).

Those examples show that "even when social capital is beneficial to a focal actor, it can have negative consequences for the broader aggregates of which that actor is a part" (Adler \& Kwon, 2002, p. 22). Regional bonding and bridging social capital were fragmented, which hindered collaboration of regional firms and municipalities during a long period. In 2001, the Heberlein enterprise closed its doors.

Another example is the employers' association the most influential textile manufacturers of the colour-weaving industry created in 1848 (see table 3, outcome 1) to bind the employees to their firms (Fischer \& Oberli, 1993). Although they could strengthen the bonding social capital of their members, they probably excluded firms of other industries. It makes sense to assume that this led to a weakening of regional bonding social capital.

To summarize, regional engagement favouring one or several large and influential firm(s) seems to have negative effects on regional social capital. The Heberlein enterprise has shaped the history of Toggenburg for a long period. Although this family engaged for their employees and the local municipality, where they also had political power via public offices (Anderegg, 2015), their engagement was often exclusive from a regional firms' point of view. The specific industrial constellation of Toggenburg, characterized by the dominance of the Heberlein enterprise, a weaving mill in the adjacent municipality, the union of some smaller firms and the tourism industry in the upper valley hindered a successful regional collaboration, which has effects until today. 


\subsubsection{Collaboration between firms from the textile industry in the Rhine Valley}

In the Rhine Valley, only two outcomes belong to the category "engagement based on exclusive agency for exclusive benefit" (see table 4).

Table 4. Outcomes of regional engagement of firms and impact on regional social capital in the Rhine Valley (exclusive agency for exclusive benefit).

\begin{tabular}{|c|c|}
\hline \multicolumn{2}{|c|}{ Phase 2: 1880 s to 1920 s "Boom of the embroidery industry" } \\
\hline Outcome 4 & 1908: Creation of an industrial association of the Rhine Valley (textile industry) \\
\hline Impact on $\mathrm{RSC}^{*}$ & Rather weakening RSC \\
\hline \multicolumn{2}{|c|}{ Phase 3: 1920s to 1980s "Diversification of industries" } \\
\hline Outcome 7 & 1936: Creation of the employers' association (textile industry) \\
\hline Impact on RSC & rather weakening RSC \\
\hline
\end{tabular}

First, the son-in-law and successor of Jacob Rohner (founder of an embroidery enterprise in 1873) created an employers' association that was established against the background of a workers' strike and aimed at conserving the firm owners' interests vis-à-vis their employees (Heuscher, 2004b) (see table 4, outcome 4). The second was the creation of the predecessor of today's employers' association back in 1936 (see table 4, outcome 7). The primary aim of its members was to preserve their common interests regarding cross-border commuters, who were indispensable employees for the industry of the Rhine Valley (Müller, 1986). Firms not belonging to the textile industry were excluded in both cases. While social capital of the members could be strengthened, overall regional bonding social capital seems to have been weakened. The second employers' association however, has accepted firms from any industry as members to gain influence from 1946 and evolved into an important actor of regional engagement for inclusive benefit that still exists today (Müller, 1986).

To conclude, when only members of one industry collaborate, this seems to strengthen withingroup social capital, it however seems to weaken regional social capital of firms, unless different groups collaborate.

\subsection{Inclusive agency for inclusive benefit}

\subsubsection{Long-term formal collaboration in the Rhine Valley}

Regional engagement based on inclusive agency generating inclusive benefit has the potential to strengthen regional social capital, as the examples below show.

The contribution to socio-economic development is quite evident in the case of the employers' association of the Rhine Valley. When the association decided to accept members from all 
industries in 1946, they started to engage for inclusive benefit. Through their activities, they succeeded in strengthening bonding and bridging social capital at a regional and a supraregional level. They have strengthened bonding social capital by collaborating for regional interests, such as cross-border issues, as large parts of the firms in the Rhine Valley depend on work force from the other side of the border (Müller, 1986). This engagement generated several contracts (see table 5, outcomes 11, 12,13).

Table 5. Outcomes of regional engagement of firms and impact on regional social capital in the Rhine Valley (inclusive agency for inclusive benefit).

\begin{tabular}{l|l}
\hline Phase 3: 1920s to 1980s "Diversification of industries" \\
\hline Outcome 8 & $\begin{array}{l}\text { 1970: Opening of the technical school Buchs, today University of Applied } \\
\text { Sciences }\end{array}$ \\
\hline Impact on RSC* & Rather strengthening (supra-)RSC \\
\hline Outcome 9 & 1971: Image campaign \\
\hline Impact on RSC & Rather strengthening RSC \\
\hline Outcome 10 & 1975: Creation of the high school Heerbrugg \\
\hline Impact on RSC & Effects on RSC uncertain \\
\hline Outcome 11 & 1977: Convention on the double taxation with Austria \\
\hline Impact on RSC & Effects on RSC uncertain \\
\hline Outcome 12 & $\mathbf{1 9 7 9 :}$ Treaty in cross-border commuters' favour \\
\hline Impact on RSC & Effects on RSC uncertain \\
\hline Phase 4: 1980s to 2015 "Structural industrial change" \\
\hline Outcome 13 & $\begin{array}{l}\text { 1992: Simplification of the authorization procedures for cross-border } \\
\text { commuters }\end{array}$ \\
\hline Impact on RSC & Effects on RSC uncertain \\
\hline Outcome 15 & $\mathbf{1 9 9 9 :}$ Creation of the association "Chancental Rheintal" \\
\hline Impact on RSC & Rather strengthening RSC \\
\hline Outcome 16 & $\mathbf{2 0 0 2 : ~ C r e a t i o n ~ o f ~ t h e ~ I n t e r n a t i o n a l ~ s c h o o l ~ R h i n e ~ V a l l e y , ~ B u c h s ~}$ \\
\hline Impact on RSC & Rather strengthening (supra-) RSC \\
\hline Outcome 17 & $\mathbf{2 0 0 2 : ~ P r o j e c t ~ " s c h o o l ~ a n d ~ e c o n o m y " ~}$ \\
\hline Impact on RSC & Rather strengthening RSC \\
\hline Outcome 18 & $\begin{array}{l}\mathbf{2 0 0 5 : ~ C r e a t i o n ~ o f ~ t h e ~ a s s o c i a t i o n ~ " S t . ~ G a l l e r ~ R h e i n t a l " ~ f o r ~ r e g i o n a l ~} \\
\text { development }\end{array}$ \\
\hline Impact on RSC & Rather strengthening RSC \\
\hline Outcome 19 & 2007: Creation of the association "Chance Industrie Rheintal" \\
\hline Impact on RSC & $\begin{array}{l}\text { Rather strengthening RSC } \\
\text { *RSC: Regional social capital. }\end{array}$ \\
\hline
\end{tabular}

Another important activity is the promotion of the dual vocational training system (educational system that consists of a parallel education in an enterprise and at a vocational school). This represents another way to counter the typical lack of employees in peripheral regions. The employers' association could create a milieu of trust and collaboration for mutual benefit (see Putnam, 1995) through this long-term engagement.

As to bridging social capital, the employers' association has engaged in improving collaboration between firms and municipalities by inviting them to participate in a regional 
image campaign in 1971 (Müller, 1986) (see table 5, outcome 9). In 1999, the employers' association under the leadership of the then-president started a first attempt to institutionalise this collaboration by creating the association "Chancental Rheintal" (see table 5, outcome 15). This was a prototype for the regional development association "St. Galler Rheintal”, which was created in 2005 (see table 5, outcome 18). Paul comments:

\section{[...] the awareness had to be raised together with all the municipalities from the} Rhine Valley that we have to work together. It was very difficult at the beginning and at the end it is a question of money [...] but it was established and pioneering work was done (Paul RV, 2014).

René underlines that "the collaboration with the municipalities - above all - takes place in the association 'St. Galler Rheintal'” (René RV, 2014). It is an important place, where representatives of the municipalities and the employers' association meet. Bernd highlights: “We have a very good employers' association, I mean, we can effectuate something, which is known and approved beyond regional frontiers, that we have succeeded in bringing together different groups" (Bernd RV, 2015). Although collaboration does not always seem to be easy, the employers' association engaged a lot to improve it. Additionally, they have engaged for the collaboration between firms and schools through participating in the project "school and economy" (created in 2002, see table 5, outcome 17) that organizes 13 events a year at schools to inform the students about apprenticeships and the way to apply for jobs. Another example are the activities of the association "Chance Industrie Rheintal" (see table 5, outcome 19), which has the aim to inform the youth about working in an enterprise. This is a good example for collaboration between different actors (bridging social capital), as Bernd underlines:

Many other employers' associations come to us and ask: how do you do that? I know all the heads of the regional high schools [...] and they aim at educating their students in a way that helps the region [...] I think this is really unique what we are doing here through a close cooperation with the schools (Bernd $R V$, 2014).

Through collaboration with employers' associations of the adjacent Swiss and Austrian regions and Liechtenstein, the employers' association has also influenced supra-regional bonding social capital, as Paul confirms: 
Where we also have a close contact is to the adjacent employers' associations, [...] to the Chamber of Industry and Commerce Vorarlberg [Austria], the industrial association in Vorarlberg [...] the same in Liechtenstein, the same [regarding] the employers' association Werdenberg [adjacent Swiss region in the south] [...] and Rorschach [adjacent Swiss region in the north], too (Paul $R V, 2014)$.

The employers' association could benefit from and strengthen supra-regional collaboration by participating in the creation of a technical school (1970, see table 5, outcome 8) and an international school (2002, see table 5, outcome 16), both located in the adjacent Swiss region. Through supra-regional collaboration, the probability to attract a critical mass of students is much higher.

The advantage of regional engagement in the form of associations is that collaboration outlasts the engagement of individuals. Associations are also more resistant with regard to opportunistic behaviour of individuals, as they can be sanctioned (Freitag et al., 2014). Nevertheless, key persons seem to play an important role, as Adrian underlines: "there are extremely engaged people here since the beginning of the 90s" (Adrian RV, 2015).

There is one outcome left, namely the establishment of the high school in Heerbrugg in 1975 (see table 5, outcome 10). It is however uncertain if this engagement could influence social capital at a regional level, especially when considering that two regional municipalities were competing for its location (Rohner, 2014).

To summarize, formal associations seem to have a huge potential to influence positively bonding and bridging social capital of regional firms, as the example of the employers' association of the Rhine Valley shows. Key persons seem to play an important role as initiators of projects. Moreover, the members seem to trust that association, which has had a long experience in engaging for common interests.

\subsubsection{Formal collaboration in its infancy in Toggenburg}

In Toggenburg, engagement based on inclusive agency for inclusive benefit differs from engagement in the Rhine Valley in many regards. For example, the region-wide employers' association of Toggenburg was only created in 1986 (see table 6, outcome 13). 
Table 6. Outcomes of regional engagement of firms and impact on regional social capital in Toggenburg (inclusive agency for inclusive benefit).

\begin{tabular}{l|l}
\hline Phase 2: 1880s to 1920s "Boom of the embroidery industry" \\
\hline Outcome 5 & $\begin{array}{l}\text { 1910: Opening of the Bodensee-Toggenburg railway segment St. Gallen- } \\
\text { Wattwil }\end{array}$ \\
\hline Impact on RSC* & Effects on RSC uncertain \\
\hline Phase 3: 1920s to 1980s "Growth and boom of the Heberlein enterprise" \\
\hline Outcome 11 & 1970: Establishment of a regional bus service \\
\hline Impact on RSC & Rather strengthening RSC \\
\hline Outcome 12 & 1970: Creation of the high school Wattwil \\
\hline Impact on RSC & Effects on RSC uncertain \\
\hline Phase 4: 1980s to 2015 "Structural industrial change and closing of the Heberlein enterprise" \\
\hline Outcome 13 & $\mathbf{1 9 8 6 :}$ Creation of a regional employers' association \\
\hline Impact on RSC & Rather strengthening RSC \\
\hline Outcome 14 & $\mathbf{1 9 6 9 - 2 0 1 5 : ~ D i f f e r e n t ~ t r a f f i c ~ b y p a s s e s ~}$ \\
\hline Impact on RSC & Effects on RSC uncertain \\
\hline Outcome 15 & $\mathbf{2 0 0 6 : ~ C r e a t i o n ~ o f ~ t h e ~ a s s o c i a t i o n ~ t o g g e n b u r g . c h ~ f o r ~ r e g i o n a l ~ d e v e l o p m e n t ~}$ \\
\hline Impact on RSC & Should strengthen RSC \\
\hline Outcome 16 & $\mathbf{2 0 1 0 : ~ P r o j e c t ~ " K o n z e p t + " ~ ( i m a g e ~ c a m p a i g n ) ~}$ \\
\hline Impact on RSC & Should strengthen RSC \\
\hline Outcome 17 & From 2013 on: Location and renovation of the high school Wattwil \\
\hline Impact on RSC & Effects on RSC uncertain \\
\hline Outcome 18 & $\mathbf{2 0 1 3 : ~ P r o j e c t ~ " T o g g e n b u r g e r ~ M a n i f e s t " ~}$ \\
\hline Impact on RSC & Effects on RSC uncertain \\
\hline Outcome 19 & $\begin{array}{l}\mathbf{2 0 1 3 : ~ L e t t e r ~ t o ~ t h e ~ p r e s i d e n t s ~ o f ~ t h e ~ m u n i c i p a l i t i e s ~ t o ~ e n c o u r a g e ~ t h e m ~ t o ~ w o r k ~} \\
\text { together }\end{array}$ \\
\hline Impact on RSC & $\begin{array}{l}\text { Should strengthen RSC } \\
\text { *RSC: Regional social capital. }\end{array}$ \\
\hline
\end{tabular}

This is due to the long-lasting predominance of the Heberlein enterprise, which often engaged for individual interests, and the creation of an employers' association at a municipal level, which still exists today. Moreover, it was the head of the cantonal office for industry, commerce and employment who motivated the firms to do so, which underlines the extrinsic character of the motivation. Jakob says: "You have to force the entrepreneurs from Toggenburg to do what is good for them, that means that they are not very organized, normally" (Jakob TB, 2014). Nevertheless, the creation of this association could strengthen regional bonding social capital of firms, as Emil highlights:

[Out of this association] good things have developed [...], the industrial enterprises exchange information and work together [...] for the training, they work together concerning the [product] development [...] earlier on they had not known what the others were doing, now they approach each other and exchange (Emil TB, 2014). 
Emil adds that only a few enterprises engage, i.e. "[...] rather the bigger enterprises, those that have a certain weight" (Emil TB, 2014). Similar to the Rhine Valley, the engagement of the employers' association seems to be strongly related to the personality of key persons, such as the president, as Jakob highlights: "either the president does something or he does not do anything" (Jakob TB, 2014). He underlines: "But it always depends on the person, not the organisation itself." Several interviewees mentioned a lack of time as the main problem not to engage (Albert TB, 2014; Emil TB, 2014; Alain TB, 2014), Especially when starting or taking over a business, time for regional engagement is often missing, which is however important to maintain social capital (Adler \& Kwon, 2002).

As to bridging social capital, the idea of increased regional cooperation began to take root in 1970 as the Heberlein family initiated the establishment of a bus service, as not all of their employees lived within walking distance (Calderara, 2012) (see table 6, outcome 11). Other regional enterprises, representatives of three municipalities and the commerce, an enterprise and a Swiss retail trade from the cantonal capital (BLWE, 2015) participated in the project. It was however difficult to bring together those different actors (Calderara, 2012). The creation of a regional development association in 2006 (see table 6, outcome 15) and its projects, such as an image campaign or the project "Toggenburger Manifest" (see table 6, outcomes 16 and 18) with the aim of supporting and accompanying important cantonal investments for Toggenburg (Schmid, 2013) also influenced regional bridging social capital. Nevertheless, collaboration especially between the municipalities seems to be rather difficult, as Georg underlines:

[...] but the regional feeling of togetherness, everybody somehow only cares for himself, this is also a problem. I think Wattwil is the centre of Toggenburg, and some years ago one had to vote, if a sports centre should be built there [...] and finally the municipalities did not stand together [...] (Georg TB, 2014).

This lack of collaboration was the reason for some firms to write a letter to the presidents of the municipalities (see table 6, outcome 19), without visible success, however: "We made an advance to the presidents of the municipalities Ebnat-Kappel, Wattwil and Lichtensteig to [motivate them] to merge. This was kindly ignored [...]" (Martin TB, 2014). But this engagement took place only in 2013. Therefore, long-term trust and the willingness to collaborate between the municipalities have been missing.

Isidor Grauer-Frey and other representatives from the embroidery industry engaged for a railway connection at the beginning of the 20th century (see table 6 , outcome 5 ). By supporting 
the regional high school in 1970 to be located in Toggenburg and in 2013 to be renovated and to stay there (see table 6, outcomes 12 and 17), regional firms engaged for structural development, too. Some firms also took interest in the transport infrastructure (see table 6, outcome 14), but it seems to be quite difficult to find common solutions, as there are many different interests (Martin TB, 2014). Those examples are rather isolated ones and an influence on regional social capital in the form of collaboration is uncertain. Supra-regional collaboration in Toggenburg does not seem to be very much developed.

In Toggenburg as well, there are examples of engagement based on inclusive agency for inclusive benefit, which have the potential to strengthen regional social capital of firms. However, that engagement is still in its infancy. No case of regional engagement based on inclusive agency for exclusive benefit was identified in the two regions.

\subsection{Exclusive agency for inclusive benefit}

\subsubsection{Pioneer engagement of firms from the textile industry in Toggenburg}

In both regions, engagement of local firms based on exclusive agency, creating - deliberately or not - inclusive benefit, could be identified. Its influence on regional social capital is uncertain.

In Toggenburg, eleven firms of the textile industry created a bank (see table 7, outcome 2) during the boom of the colour-weaving industry that benefited large parts of regional firms (Fischer \& Oberli, 1993).

Table 7. Outcomes of regional engagement of firms and impact on regional social capital in Toggenburg (exclusive agency for inclusive benefit).

\begin{tabular}{|c|c|}
\hline Outcome 2 & 1863: Establishment of the Toggenburger Bank \\
\hline Impact on RSC & Effects on RSC uncertain \\
\hline Outcome 3 & 1870: Opening of the Toggenburger railway segment Wil-Ebnat \\
\hline Impact on RSC & Effects on RSC uncertain \\
\hline \multicolumn{2}{|c|}{ Phase 2: 1880s to 1920s "Boom of the embroidery industry" } \\
\hline Outcome 4 & 1881: Establishment of the "Toggenburger weaving school" \\
\hline Impact on RSC & Effects on regional social capital uncertain \\
\hline Outcome 6 & 1907-1917: River Thur correction \\
\hline Impact on RSC & Effects on RSC uncertain \\
\hline
\end{tabular}

Another example is the engagement of several representatives of the textile industry for the railway in the same phase (see table 7, outcome 3) or the commitment of Georges Heberlein for the river training which favoured the whole region (see table 7, outcome 6). Moreover, the textile entrepreneur Fritz Abderhalden tried to avert the crisis of the colour-weaving industry by supporting the establishment of a weaving school, which opened its doors in 1881 (see table 
7, outcome 4) to better form work force. This engagement's influence on regional social capital is uncertain.

\subsubsection{Engagement of key persons for inclusive benefit over time in the Rhine Valley}

In the Rhine Valley, the entrepreneur and teacher Karl Völker engaged for the correction of the river Rhine and the railway by trying to convince the municipalities and their population of the benefits of a railway back in the 19th century (Bruderer, 2014) (see table 8, outcome 1).

Table 8. Outcomes of regional engagement of firms and impact on regional social capital in the Rhine Valley (exclusive agency for inclusive benefit).

\begin{tabular}{|c|c|}
\hline \multicolumn{2}{|c|}{$\begin{array}{l}\text { Phase 1: Beginning of the } 19^{\text {th }} \text { century to } 1880 \mathrm{~s} \text { "Dominance of cotton spinning, weaving and } \\
\text { manual embroidery" }\end{array}$} \\
\hline Outcome 1 & $\begin{array}{l}\text { 1858: Opening of the railway segment Rorschach-Chur as a part of the } \\
\text { planned train connection to Italy }\end{array}$ \\
\hline Impact on RSC & Effects on RSC uncertain \\
\hline \multicolumn{2}{|c|}{ Phase 2: 1880 s to 1920 s "Boom of the embroidery industry" } \\
\hline Outcome 2 & 1897: Opening of the Rhine Valley tramway \\
\hline Impact on RSC & Effects on RSC uncertain \\
\hline Outcome 3 & 1908: Creation of a commercial continuation school \\
\hline Impact on RSC & Effects on RSC uncertain \\
\hline \multicolumn{2}{|c|}{ Phase 3: 1920s to 1980s "Diversification of industries" } \\
\hline Outcome 5 & 1921: Creation of the Wild enterprise \\
\hline Impact on RSC & Effects on RSC uncertain \\
\hline Outcome 6 & $\begin{array}{l}\text { 1924: Training centre of the Wild enterprise (today Leica Geosystems), later } \\
\text { on (1930) vocational school for fine mechanics and optics }\end{array}$ \\
\hline Impact on RSC & Effects on RSC uncertain \\
\hline \multicolumn{2}{|c|}{ Phase 4: 1980s to 2015 "Structural ind ustrial change" } \\
\hline Outcome 14 & 1997: Hans Huber foundation (for the promotion of the vocational education) \\
\hline Impact on RSC & Effects on RSC uncertain \\
\hline
\end{tabular}

Then, Jacob Schmidheiny (the father of an important firm founding family) and a regional merchant initiated the construction of a tramway, as the municipalities of the Rhine Valley were not well connected by public transport at a local level (see table 8 , outcome 2 ). The heads of two important embroidery companies, Jacob Rohner and Fidel Eugster, played an important role in the financial support. Jacob Rohner was very eager for the project to be successful as the tramway connected different locations of his enterprise. Finally, the whole region could benefit (Schweizer, 1999). Jacob Rohner also engaged for the creation of a commercial school, which benefited the region (see table 8, outcome 3). Another example is the training centre of the Wild enterprise (see table 8, outcome 6). The entrepreneurs Jacob Schmidheiny (the son of the above Jacob Schmidheiny), Heinrich Wild and Robert Helbling introduced the optics and fine mechanics industry into the Rhine Valley after the crisis of the embroidery industry by creating this enterprise in 1921 (Simmen, 1991) (see table 8, outcome 5). Jacob Schmidheiny 
agreed to support the project financially on condition that the enterprise was located in the Rhine Valley to create jobs for the population after the crisis (Beutler, 1954). This underlines his strong attachment to and therefore embeddedness in the region. The training centre was first opened for precision engineers and metal workers, from 1926 for opticians, too. Many of the apprentices could stay at the Wild enterprise, others found a workplace in smaller firms in the region and some of them became founders of new enterprises. The formation at the Wild enterprise has been regarded as a cornerstone for the dual vocational training system to be so strong in the region (Voit, 2015). Another example is a foundation the entrepreneur Hans Huber created for the promotion of vocational education, too (see table 8 , outcome 14). These are examples of engagement not only the person who engages benefits, irrespective of wanting or not. Sometimes, regional engagement is based on interests of an individual or a small group, but finally has "externalities" that may affect "bystanders" (Putnam, 2000). This engagement illustrates again the importance of key persons, whose engagement benefits the whole region. However, they do probably not influence regional social capital in the form of collaboration.

\section{Discussion}

The findings show that regional engagement based on exclusive agency for exclusive benefit has the potential to weaken, regional engagement based on inclusive agency for inclusive benefit to strengthen overall regional social capital. Regional engagement based on exclusive agency for inclusive benefit does not seem to influence regional social capital in terms of collaboration.

Table 9 gives an overview of the different outcomes (O1, $\mathrm{O} 2$ etc.) of regional engagement in the two regions over time and indicates if it weakened (w) or strengthened (s) regional social capital of firms or if effects on social capital are uncertain (u). It is based on the analytical framework introduced above. 
Table 9. Comparison of outcomes $(\mathrm{O1}, \mathrm{O2}$ etc.) of regional engagement and its influence on regional social capital in Toggenburg and Rhine Valley over time.

\begin{tabular}{|c|c|c|c|c|c|}
\hline \multirow{5}{*}{ 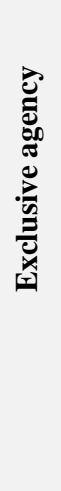 } & \multicolumn{2}{|c|}{ For exclusive benefit } & \multicolumn{3}{|c|}{ For inclusive benefit } \\
\hline & Toggenburg & Rhine Valley & Phase & Toggenburg & Rhine Valley \\
\hline & $\mathrm{O} * 1 \mathbf{w}$ & & $\begin{array}{c}\text { Phase 1: } \\
\text { Beginning of the } \\
19^{\text {th }} \text { century to } \\
1880 \mathrm{~s}\end{array}$ & $\mathrm{O} 2 \mathbf{u}, \mathrm{O} 3 \mathbf{u}$ & O1u \\
\hline & & $\mathrm{O} 4 \mathrm{w}$ & $\begin{array}{c}\text { Phase 2: } 1880 \text { s to } \\
1920 \mathrm{~s}\end{array}$ & O4u, O6u & $\mathrm{O} 2 \mathbf{u}, \mathrm{O} 3 \mathbf{u}$ \\
\hline & $\begin{array}{l}\text { O7w, C8w, } \\
\text { O9w, O10w }\end{array}$ & O7w & $\begin{array}{c}\text { Phase 3: } 1920 \mathrm{~s} \text { to } \\
1980 \mathrm{~s}\end{array}$ & & O5u, O6u \\
\hline \multirow{6}{*}{ 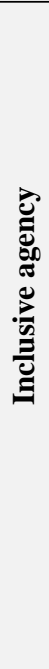 } & & & $\begin{array}{c}\text { Phase 4: } 1980 \text { s to } \\
2015\end{array}$ & & O14u \\
\hline & Toggenburg & Rhine Valley & Phase & Toggenburg & Rhine Valley \\
\hline & & & $\begin{array}{c}\text { Phase 1: } \\
\text { Beginning of the } \\
19^{\text {th }} \text { century to } \\
1880 \mathrm{~s}\end{array}$ & & \\
\hline & & & $\begin{array}{c}\text { Phase 2: } 1880 \mathrm{~s} \text { to } \\
1920 \mathrm{~s}\end{array}$ & O5u & \\
\hline & & & $\begin{array}{c}\text { Phase 3: } 1920 \mathrm{~s} \text { to } \\
1980 \mathrm{~s}\end{array}$ & O11s, O12u & $\begin{array}{l}\text { O8s, O9s, O10u, } \\
\text { O11u, O12u }\end{array}$ \\
\hline & & & $\begin{array}{c}\text { Phase 4: } 1980 \text { s to } \\
2015\end{array}$ & $\begin{array}{l}\text { O13s, O14u, } \\
\text { O15s*, } \\
\text { O16s*, O17u, } \\
\text { O18u, O19s* }\end{array}$ & $\begin{array}{l}\mathrm{O} 13 \mathbf{u}, \mathrm{O} 15 \mathbf{s}, \\
\mathrm{O} 16 \mathbf{s}, \mathrm{O} 17 \mathbf{s}, \\
\mathrm{O} 18 \mathbf{s}, \mathrm{O} 19 \mathbf{s}\end{array}$ \\
\hline
\end{tabular}

*O: Outcome. s: strengthening regional social capital / *s: should strengthen regional social capital / w: weakening regional social capital / u: uncertain influence.

When comparing regional engagement of firms in the two regions over time, different patterns of regional engagement and its influence on regional social capital result. There is a clustering of regional engagement based on exclusive agency for exclusive benefit in Toggenburg in phase 3. The main actor of this engagement is the Heberlein enterprise that mainly got engaged out of individual interests. Although they contributed to structural development by building residences or a public house, which serves a public purpose today, their exclusive engagement has weakened regional social capital. Contrary to firm founders or heads of small firms e.g., who often lack the time to engage, the large-sized and old-established Heberlein enterprise had developed much power in its municipality.

In the Rhine Valley, engagement based on inclusive agency for inclusive benefit started in phase 3 and continues until today. The main actor of this engagement is the regional employers' association that decided to accept members from all industries from 1946 to engage especially for cross-border issues and later on for the promotion of the dual vocational training system. The employers' association succeeded in strengthening bonding and bridging social capital at 
a regional and supra-regional level through cross-border collaboration. Over the years, the association could create a milieu of trust and collaboration for mutual benefit (Putnam, 1995). In Toggenburg, this kind of engagement is more recent; therefore, its effects on bonding and bridging social capital are still in its infancy, which is related to the long dominance of the Heberlein enterprise and therefore Toggenburg's industrial history.

In both regions, engagement in the form of exclusive agency for inclusive benefit could be identified. In Toggenburg, this kind of engagement concentrates on phases 1 and 2, in the Rhine Valley however, on all phases. The commitment of key persons who engage out of regional or individual interests by influencing structural development, such as public transport, seems to be crucial. An important example in the Rhine Valley is the engagement of Jacob Schmidheiny who financed the creation of the Wild enterprise on condition that it is located in his home region. An influence of this type of engagement on regional collaboration is uncertain. Key persons seem to play an important role in formal associations, too. Especially in the Rhine Valley, many presidents of the employers' association have engaged to improve their regional framework. In Toggenburg however, the presidents' engagement seems to be more unstable, which could be related to the rather short experience in institutionalised regional collaboration. This supports Putnam's argument, that an individual is more productive in a well-connected region than "a well-connected individual in a poorly connected" (2000, p. 20) region. In accordance with the theoretical assumptions, firms in the dynamic region Rhine Valley could contribute to socio-economic development by building high levels of regional bonding and bridging social capital over time. In the less dynamic Toggenburg, region-wide bonding and bridging social capital are still at lower levels.

When asking for the "why" of those differences, the most important factor seems to be the willingness of firms and other actors, such as municipalities to collaborate for regional interests at a regional and supra-regional level. This reflects the subjective, cultural dimension of social capital. When the actors are willing to collaborate, they can influence the objective, structural dimension of social capital by creating durable, institutionalized networks. On the other hand, those institutionalized networks seem to play an important role to strengthen the willingness of actors to cooperate, too (see van Oorschot, 2006). This is a mutually reinforcing interplay, which becomes particularly obvious from a historical perspective. The regional industrial mix can impair that willingness. For example, in Toggenburg, the interests of the manufacturing industry (lower valley) and the tourism industry (upper valley) are not necessarily the same, which hinders collaboration. Then, the power and size of the enterprises that engage seem to 
play a crucial role. When a huge firm, such as the Heberlein enterprise, which had also a lot of political power, engages for individual interests, regional collaboration is very difficult. This was the case regarding labour force recruitment. In the Rhine Valley, the firms have also struggled with a lack of labour force. However, they (huge firms included) decided to collaborate at a regional level. To succeed in collaborating, formal institutions including firms (bonding social capital) or firms and other actors (bridging social capital) seem to be crucial, as regional engagement in formal institutions outlasts the engagement of individuals and actors that do not behave adequately can be sanctioned (Freitag et al., 2014). For collaboration to be successful and based on high levels of trust, long-term experience is indispensable. The willingness to collaborate for regional concerns also seems to be strongly related to a regional feeling of togetherness, i.e. the social cohesion, the culture and attitudes of the economic actors of the region (Callois \& Aubert, 2007; Hjalager, 1989).

To sum up, when regional firms and other actors are willing to collaborate for regional interests, they can shape regional contexts through regional engagement that leads to socio-economic development of the whole region. When firms engage for individual interests and regional collaboration is missing, a region potentially grows in terms of employees or tax incomes, not however in a more socio-economic sense.

\section{Conclusion}

This study investigates how regional engagement of firms influences regional social capital and therefore regional socio-economic development. The findings show that firms in peripheral regions, among them many family and/or long-established firms, interact with their community and place and strengthen their socio-spatial embeddedness through regional engagement by shaping regional endowments and social capital, which confirms and completes the findings of previous studies (McKeever et al., 2015; Vestrum, 2014; Kibler et al., 2015). However, regional engagement does not only have positive effects for regional firms; it can strengthen regional social capital, but it also has the potential to weaken it, as the example of the Heberlein enterprise shows. In accordance with the theoretical assumption, the findings confirm that firms in the dynamic region Rhine Valley could create higher levels of regional bonding and bridging social capital in terms of the quality of collaboration through regional engagement than firms in the less dynamic region Toggenburg over time. Formal institutions, such as the employers' association in the Rhine Valley and key persons seem to play a crucial role in successful regional engagement. Hence, place and individuals likewise should be well connected for regional socio-economic development to be successful (see Putnam, 2000). One important 
factor to explain the differences in regional social capital in the two regions, is the willingness of firms and other actors to collaborate for regional interests (see Putnam, 1993) and therefore the cultural dimension of social capital, which influences the structural dimension in terms of institutionalized networks and vice versa (see van Oorschot, 2006). The history of collaboration of a region plays an important role for the quality of present collaboration.

This study contributes to a better understanding of the role of firms for socio-economic development of peripheral regions by contextualizing economic action. The study examines how local firms influence regional contexts, which can lead to socio-economic change by drawing on the concepts of embeddedness, regional engagement and social capital. The study shows that firms can influence regional development beyond the strictly economic sense (Müller, 2016) by affecting social capital in terms of regional collaboration. It illustrates the importance of place-based engagement of firms for the development of a peripheral region (McKeever et al., 2015; Johannisson \& Nilsson, 1989) in a Swiss context. Hence, firms are very important for the building of place (McKeever et al., 2015), although regional engagement can have positive or negative effects for firms and collaboration at an aggregated level. The study depicts that places are "complex systems of social relations and material objects" (McKeever et al., 2015, p. 3). It illustrates that economic action shapes place and social structure and vice versa (see Uzzi, 1997). Moreover, the study helps to explain differences in development paths in peripheral regions, which have long been "treated as one and the same" (Müller 2016, p. 1148).

Policy-makers should be aware of the heterogeneity of peripheral regions, the potential value of engagement of firms and the importance of bonding and bridging social capital of firms at a regional and extra-regional level for regional development. There is a need to adopt a long-term perspective to understand the current situation.

As this is a case study, future research should verify the present results in other peripheral regions. Moreover, it would be interesting to measure quantitatively the levels of social capital of firms in dynamic and less dynamic peripheral or urban regions. Further, it would also be valuable to examine effects of regional engagement at the firm level.

\section{Acknowledgement}

I would like to thank Heike Mayer, Tina Haisch and Birgit Leick for their helpful comments. I am particularly grateful to the two reviewers for their most valuable advice and support. 


\section{Funding}

The research for this article was funded by the Swiss National Science Foundation (Grant 146436).

\section{References}

Adler, P. S., \& Kwon, S. W. (2002). Social capital: prospects for a new concept. The Academy of Management Review, 27(1), 17-40.

Amann, H. (1990). Mit Dampf ins Toggenburg - 120 Jahre Toggenburger Bahn [With steam towards the Toggenburg - 120 years Toggenburger railway]. In Toggenburger Annalen. Bazenheid: E. Kalberer AG.

Anderegg, B. (2011, December 7). Chancen durch Nischenprodukte [Chances through niche products]. St. Galler Tagblatt Online. Retrieved from http://www.tagblatt.ch/ostschweiz/stgallen/toggenburg/tt-ne/Chancen-durchNischenprodukte; art236,2785875

Anderegg, B. (2012, June 8). Robin Alder neuer AGV - Präsident [Robin Alder new president of the employers' association Rhine Valley]. St. Galler Tagblatt Online. Retrieved from http://www.tagblatt.ch/ostschweiz/stgallen/toggenburg/tt-au/Robin-Alder-neuer-AGVPraesident;art233,3009475

Anderegg, B. (2015). “Wir sind Heberlianer!” Heberlein, seine Mitarbeitenden und das Dorf Wattwil ['We are Heberlianer! Heberlein, his employees and the village of Wattwil]. In H. Büchler (Ed.), Heberlein 1835-2015. Von der Lohnfärberei zum Industriekonzern (pp. 170-197). Schwellbrunn: Toggenburger Verlag.

Anderson, A. R. (2000). Paradox in the periphery: an entrepreneurial reconstruction? Entrepreneurship \& Regional Development, 12(2), 91-109.

Baumgartner, D., Pütz, M., \& Seidl, I. (2013). What kind of entrepreneurship drives regional development in European non-core regions? A literature review on empirical entrepreneurship research. European Planning Studies, 21(8), 1095-1127.

Beutler, R. (1954). Die optisch-feinmechanische Industrie im sanktgallischen Rheintal [The optical-fine mechanical industry in the Rhine Valley]. Handels-Hochschule St. Gallen.

BLWE (Busbetrieb Liechtenstein-Wattwil-Ebnat-Kappel). (n.d.). Busbetrieb "Lichtensteig Wattwil - Ebnat-Kappel” Portrait [Bus service "Lichtensteig-Wattwil-Ebnat-Kappel” portrait]. Retrieved November 18, 2015, from 
http://www.blwe.ch/index.php?TPL=10073

Bourdieu, P. (1986). The forms of capital. In J. Richardson (Ed.), Handbook of Theory and Practice for the Sociology of Education (pp. 241-258). New York: Greenwood.

Bruderer, G. (2014, July 19). Strassennamen Wer ist ... Karl Völker? [Street names Who is ... Karl Völker?]. St. Galler Tagblatt Online. Retrieved from http://www.tagblatt.ch/tbnews/tbrt/rt-in/STRASSENNAMEN-Wer-ist-KarlVoelker;art905,3893992

Büchler, H. (1997). Wattwil. Zentrumsgemeinde im Toggenburg [Wattwil. Central municipality in the Toggenburg]. Wattwil: Gemeinde Wattwil.

Calderara, J. (2012, October 4). Selbsthilfe als Leitgedanke [Self-help as a guiding principle]. St. Galler Tagblatt Online. Retrieved from http://www.tagblatt.ch/ostschweiz/stgallen/toggenburg/tt-au/Selbsthilfe-alsLeitgedanke;art233,3149535

Callois, J. M., \& Aubert, F. (2007). Towards indicators of social capital for regional development issues: the case of French rural areas. Regional Studies, 41(6), 809-821.

Coleman, J. S. (1988). Social capital in the creation of human capital. American Journal of Sociology, 94, 95-120.

Denzin, N. K. (1978). The research act: a theoretical introduction to sociological methods. New York: McGraw-Hill.

Die neue Regionalpolitik [New Regional Policy]. (2007, May 10). St. Galler Tagblatt Online. Retrieved from http://www.tagblatt.ch/altdaten/tagblatt-alt/tagblattheute/tt/ttre/art812,81957

Doloreux, D., Dionne, S., \& Jean, B. (2007). The evolution of an innovation system in a rural area: the case of La Pocatière, Québec. International Journal of Urban and Regional Research, 31(1), 146-167.

Eggenberger, J. (1995). 25 Jahre Interstaatliche Ingenieurschule Neu-Technikum Buchs: 1970 bis 1995 [25 years interstate engineering school new technical centre Buchs: 1970 to 1995]. Buchs: NTB-Studienstiftung.

Eisenhardt, K. M., \& Graebner, M. E. (2007). Theory building from cases: opportunities and challenges. Academy of Management Journal, 50(1), 25-32.

Fischer, T., \& Oberli, H. (1993). Die Industrialisierung des Toggenburgs [The industrialisation of Toggenburg]. In Das Toggenburg. Eine Landschaft zwischen Tradition und Fortschritt [Toggenburg, a landscape between tradition and progress] (pp. 78-98). Sulgen: Verlag Niggli AG. 
Fischer, T., \& Oswald, R. (1997). Industrie im Wandel [Changing Industry]. In H. Büchler (Ed.), Wattwil. Zentrumsgemeinde im Toggenburg [Wattwil. Central municipality in Toggenburg] (pp. 159-187). Wattwil: Gemeinde Wattwil.

Freitag, M., Ackermann, K., Bauer, P. C., Gundelach, B., Manatschal, A., \& Rapp, C. (2014). Das soziale Kapital der Schweiz [the social capital of Switzerland]. (M. Freitag, Ed.). Zürich: Verlag Neue Zürcher Zeitung.

Fukuyama, F. (1995). Trust: the social virtues and the creation of prospensity. New York: Free Press.

Gröble, O., Benson, L., \& Flockerzi, M. (2015). Regionale Disparitäten: Die Regionen der Neuen Regionalpolitik im Kanton St. Gallen [Regional disparities: the regions of the new regional policy in the canton of St. Gallen]. Statistik aktuell 49. St. Gallen:

Fachstelle für Statistik Kanton St. Gallen.

Heberlein, F., \& Bodmer, A. (1970). Georges Heberlein-Staehelin. 1874-1944. In Nekrologe und Kurzbiographien. Zürich: Verein für wirtschaftshistorische Studien.

Heberlein, R. (2015). Die Heberlein-Familien. Öffentliches und Privates [the Heberlein families. Public and private affairs]. In H. Büchler (Ed.), Heberlein 1835-2015. Von der Lohnfärberei zum Industriekonzern. (pp. 114-149). Schwellbrunn: Toggenburger Verlag.

Heblich, S., \& Gold, R. (2010). Corporate Social Responsibility: Eine Win-Win Strategie für Unternehmen und Regionen [Corporate Social Responsibility: a win-win strategy for enterprises and regions]. In H. Pechlaner \& M. Bachinger (Eds.), Lebensqualität und Standortattraktivität. Kultur, Mobilität und regionale Marken als Erfolgsfaktoren. (pp. 333-358). Berlin: Erich Schmidt.

Heuscher, S. (2004a). Albert (1868-1935) und Josy Geser-Rohner (1881-1961), Rebstein. In Rheintaler Köpfe. Historisch-biografische Porträts aus fünf Jahrhunderten. (Berneck, pp. 176-182). Verein für die Geschichte des Rheintals.

Heuscher, S. (2004b). Jacob Rohner (1852-1926), Rebstein. In Rheintaler Köpfe. Historischbiografische Porträts aus fünf Jahrhunderten. (pp. 296-302). Verein für die Geschichte des Rheintals.

Hjalager, A. (1989). Why no entrepreneurs? Lifemodes, everyday life, and unemployment strategies in an underdeveloped region. Entrepreneurship \& Regional Development, 1 , 85-97.

Holenstein, A. (2015). Neuorientierung und Aufbruch. 1896-1945. Textilveredlung und Textildruck. Dritte und vierte Generation. [Reorientation and breakup. 1896-1945. Textile finishing and textile printing]. In H. Büchler (Ed.), Heberlein 1835-2015. Von 
der Lohnfärberei zum Industriekonzern. (pp. 46-81). Schwellbrunn: Toggenburger Verlag.

Huberman, A. M., \& Miles, M. B. (1994). Data management and analysis methods. In N. K. Denzin \& Y. S. Lincoln (Eds.), Handbook of qualitative research (pp. 428-444). Thousand Oaks, CA: Sage.

International School Rheintal. (2005, April 12). St. Galler Tagblatt Online. Retrieved from http://www.tagblatt.ch/altdaten/tagblatt-alt/tagblattheute/rt/unterrheintal/rtur/art783,2100665

Jack, S. L. (2005). The role, use and activation of strong and weak network ties: a qualitative analysis. Journal of Management Studies, 42(6).

Jack, S. L., \& Anderson, A. R. (2002). The effects of embeddedness on the entrepreneurial process. Journal of Business Venturing, 17(5), 467-487.

Johannisson, B. (1990). Community entrepreneurship - cases and conceptualization. Entrepreneurship \& Regional Development, 2(1), 71-88.

Johannisson, B., \& Nilsson, A. (1989). Community entrepreneurs: networking for local development. Entrepreneurship \& Regional Development, 1(1), 3-19.

Kesselring, W. (1950). Isidor Grauer-Frey. Vater der Bodensee-Toggenburgbahn [Isidor Grauer-Frey. Father of the Bodensee-Toggenburg railway]. Degersheim.

Kesselring, W. (1960). Fünfzig Jahre Bodensee-Toggenburg-Bahn und Rickenbahn. 19101960 [50 years Bodensee-Toggenburg railway and Ricken railway]. (BodenseeToggenburg-Bahn, Ed.). St.Gallen: Zollikofer.

Kibler, E., Fink, M., Lang, R., \& Muñoz, P. (2015). Place attachment and social legitimacy: revisiting the sustainable entrepreneurship journey. Journal of Business Venturing Insights, 3, 24-29.

Kim, P. H., \& Aldrich, H. E. (2005). Social capital and entrepreneurship. Foundations and Trends in Entrepreneurship, 1(2), 55-104.

Korsgaard, S., \& Anderson, A. R. (2011). Enacting entrepreneurship as social value creation. International Small Business Journal, 29, 135-151.

Korsgaard, S., Ferguson, R., \& Gaddefors, J. (2015). The best of both worlds: how rural entrepreneurs use placial embeddedness and strategic networks to create opportunities. Entrepreneurship \& Regional Development, 27(9-10), 1-25.

Kugler, H. (2012, March 15). Hauptsache Standortförderung [Main thing location promotion]. St. Galler Tagblatt Online. Retrieved from http://www.tagblatt.ch/ostschweiz/stgallen/toggenburg/tt-au/Hauptsache- 
Standortfoerderung;art233,2903153

Lagendijk, A., \& Lorentzen, A. (2007). Proximity, knowledge and innovation in peripheral regions. On the intersection between geographical and organizational proximity. European Planning Studies, 15(4), 457-466.

Langley, A. (1999). Strategies for theorizing from process data. The Academy of Management Review, 24(4), 691-710.

Lengauer, L., \& Tödtling, F. (2010). Regional embeddedness and corporate regional engagement: evidence from three industries in the Austrian region of Styria. Paper Presented at the 8th European Urban \& Regional Studies Conference, Vienna, September 15-17 (pp. 1-31).

McKeever, E., Anderson, A., \& Jack, S. (2014). Entrepreneurship and mutuality: social capital in processes and practices. Entrepreneurship \& Regional Development, 26(5-6), $1-25$.

McKeever, E., Jack, S., \& Anderson, A. (2015). Embedded entrepreneurship in the creative re-construction of place. Journal of Business Venturing, 30(1), 50-65.

Müller, A. (1981). Rückblick auf 100 Jahre 1881-1981 Schweizerische Textilfachschule Wattwil, Zürich, St. Gallen [Review on the 100 years history 1881-1981 of the Swiss textile professional school Wattwil, Zurich, St. Gallen]. Wattwil: Buckdruckerei Wattwil AG.

Müller, H. (1986). 50 Jahre Arbeitgeber-Verband des Rheintals [50 years employers association of Rhine Valley]. (A.-V. des Rheintals, Ed.). Heerbrugg.

Müller, S. (2016). A progress review of entrepreneurship and regional development: what are the remaining gaps? European Planning Studies, 24(6), 1133-1158.

Nussmüller, E., Lengauer, L., \& Tödtling, F. (2009). Motives and influencing factors of corporate regional engagement. Discussion Papers, (4), 1-29.

Oberlin, A. (1997). Handwerk, Gewerbe und Dienstleistungen - ein goldener Boden? [Crafts, commerce and services - a golden soil?] In H. Büchler (Ed.), Wattwil. Zentrumsgemeinde im Toggenburg [Wattwil. Central municipality in the Toggenburg] (pp. 144-158). Wattwil: Gemeinde Wattwil.

Patton, M. Q. (2002). Qualitative research \& evaluation methods (3rd ed.). Saint Paul: MN: Sage Publications.

Pro Kanti Toggenburg-Linth in Wattwil. (n.d.). Retrieved January 13, 2016, from http://www.prokantiwattwil.ch/

Putnam, R. D. (1993). Making democracy work. Civic traditions in modern Italy. Princeton, 
NJ: Princeton University Press.

Putnam, R. D. (1995). Bowling alone: America’s declining social capital. Journal of Democracy, 6(1), 65-78.

Putnam, R. D. (2000). Bowling Alone: the collapse and revival of American community. New York: Simon \& Schuster.

Rohner, M. (2014, May 6). Der Rheintaler Kanti-Streit [The struggle for high school in the Rhine Valley]. St. Galler Tagblatt Online. Retrieved from http://www.tagblatt.ch/ostschweiz/ostschweiz/tb-os/Der-Rheintaler-KantiStreit;art120094,3798354

Schmid, S. (2013, August 14). Im Herzen, nicht am Rande [in the heart, not at the margin]. St. Galler Tagblatt Online. Retrieved from http://www.tagblatt.ch/ostschweiz/stgallen/toggenburg/tt-au/Im-Herzen-nicht-amRande;art233,3499891

Schreier, M. (2014). Varianten qualitativer Inhaltsanalyse: Ein Wegweiser im Dickicht der Begrifflichkeiten [Variants of qualitative content analysis: a guide in the thicket of notions]. Forum Qualitative Sozialforschung / Forum: Qualitative Social Research, 15(1), 27. Retrieved from http://www.qualitativeresearch.net/index.php/fqs/article/view/2043/3636

Schuler, M., Dessemontet, P., \& Joye, D. (2005). Eidgenössische Volkszählung 2000. Die Raumgliederungen der Schweiz. [Federal population census 2000. The spatial division of Switzerland]. (S. F. S. Office, Ed.). Neuchâtel.

Schweizer, M. (1999). Rheintalische Strassenbahnen 1898-1998 [The Rhine Valley tramway 1898-1998]. Zürich: Leutwiler.

Simmen, R. (1991). Von Wild zu Leica. 70 Jahre Firmengeschichte 1921-1991 [From Wild towards Leica. A 70 years corporate history]. Heerbrugg: Leica Heerbrugg AG.

Smallbone, D. (2009). Rural Entrepreneurship. In J. P. A. Hofer (Ed.), Strenghtening entrepreneurship and economic development in East Germany: lessons from local approaches (pp. 161-189). Paris: Organisation for Economic Co-operation and Development (OECD).

Trippl, M., Asheim, B., \& Miörner, J. (2016). Identification of regions with less developed research and innovation systems. In M. D. Parrilli, R. D. Fitjar, \& A. Rodriguez-Pose (Eds.), Innovation drivers and regional innovation strategies (pp. 23-44). New York: Routledge.

Uzzi, B. (1997). Social structure and competition in interfirm networks : the paradox of 
embeddedness. Administrative Science Quarterly, 42(1), 35-67.

van Oorschot, W. (2006). Social capital in Europe: measurement and social and regional distribution of a multifaceted phenomenon. Acta Sociologica, 49(2), 149-167.

Vestrum, I. (2014). The embedding process of community ventures: creating a music festival in a rural community. Entrepreneurship \& Regional Development, 26(7-8), 619-644.

Voit, E. (2015). Vom Armental zum High- Precision Valley - die Wilde Geschichte des Alpenrheintals [From a poor valley to a high precision valley - the wild history of the alpine rhine valley]. Géomatique Suisse, 11, 454-460.

Walder, E. (1914). Die Toggenburger Bank. 1863-1912 [The bank of Toggenburg. 18631912]. St. Gallen: Zollikofer.

Welter, F. (2011). Contextualizing entrepreneurship - Conceptual challenges and ways forward. Entrepreneurship: Theory and Practice, 35(1), 165-184.

Westlund, H., \& Bolton, R. (2003). Local social capital and entrepreneurship. Small Business Economics, 21(2), 77-113.

Westlund, H., \& Gawell, M. (2012). Building social capital for social entrepreneurship. Annals of Public and Cooperative Economics, 83(1), 101-116.

Wickli, B. (2015). Diversifikation und langer Abschied vom Toggenburg. 1946-2001 [Diversification and long farewell from Toggenburg]. In H. Büchler (Ed.), Heberlein 1835-2015. Von der Lohnfärberei zum Industriekonzern. (pp. 82-113). Schwellbrunn: Toggenburger Verlag.

Woolcock, M., \& Narayan, D. (2002). Social capital: implications for development theory and policy. The World Bank Research Observer, 15(2), 225-249. 